\title{
Renal Effects of Theophylline and Caffeine in Newborn Rabbits ${ }^{1}$
}

\author{
JEAN-BERNARD GOUYON ${ }^{2}$ AND JEAN-PIERRE GUIGNARD \\ Unité de Néphrologie [J-P.G.], Service de Pédiatrie, Centre Hospitalier Universitaire Vaudois, 1011 Lausanne, \\ Switzerland
}

\begin{abstract}
Renal hemodynamics and functions were assessed in four groups of anaesthetized newborn rabbits receiving a single intravenous dose of methylxanthines, i.e.: aminophylline: $3 \mathrm{mg} / \mathrm{kg}$ (A1) or $6 \mathrm{mg} / \mathrm{kg}$ (A2); sodium benzoate caffeine: $5 \mathrm{mg} / \mathrm{kg}$ (C1) or $10 \mathrm{mg} / \mathrm{kg}$ (C2). Each animal acted as its own control. The mean PAH extraction ratio was not modified by the methylxanthines. Renal blood flow and glomerular filtration rate were determined by clearances of paraaminohippuric acid and inulin, respectively. No changes in renal hemodynamics or renal functions were observed in group $\mathrm{C}$. In group $\mathrm{C} 2$, renal blood flow and filtration fraction did not vary significantly but renal vascular resistance showed a delayed increase. Systemic infusion of the two aminophylline regimens induced a delayed increase in renal vascular resistance with a concomitant fall in renal blood flow and an increase of filtration fraction in group A2. Glomerular filtration rate was either reduced $(3 \mathrm{mg} / \mathrm{kg}$ aminophylline) or increased $(6 \mathrm{mg} / \mathrm{kg}$ aminophylline and $10 \mathrm{mg} / \mathrm{kg}$ caffeine). Moreover, diuresis increased and tubular water reabsorption declined in groups A1, A2, and $\mathrm{C} 2$. High dose caffeine enhanced sodium fractional excretion. The acute renal effects of methylxanthines appeared dose- and time-related in immature animals and caffeine proved safer than aminophylline at doses used in human neonates. (Pediatr Res 21: 615-618, 1987)
\end{abstract}

Abbreviations

$\mathrm{V}$, urine flow rate

GFR, glomerular filtration rate

MBP, mean blood pressure

RBF, renal blood flow

RVR, renal vascular resistance

FF, filtration fraction

FENa, sodium fractional excretion

PAH, para-aminohippuric acid

Hct, hematocrit

E PAH, renal PAH extraction ratio

$U / P$ inulin, urine to plasma inulin ratio

MX, methylxanthine

PG, prostaglandin

The xanthine derivatives theophylline and caffeine are widely used and equally effective to control idiopathic apnea in pre-

Received August 1, 1986; accepted January 22, 1987.

Reprint requests Prof. J.-P. Guignard, Unité de néphrologie, Service de pédiatrie Centre Hospitalier Universitaire Vaudois, 1011 Lausanne, Switzerland.

Supported by Grant 3.808.0.86 of the Swiss National Science Foundation. J.B.G. was supported in part by Grant 3.842.0.83 of the Swiss National Science Foundation.

'Presented in part at the Annual Meeting of the Swiss Society of Nephrology, Luzern 1985.

${ }^{2}$ Present address Hôpital d'Enfants de Dijon, 21034 Dijon, Cedex, France. mature infants (1-3). Thus a precise knowledge of their respective adverse renal effects can be helpful for the therapeutic choice. In adult and experimental animals, methylxanthines act as diuretic and natriuretic agents (4), but conflicting results have been obtained in several studies assessing the renal effects of theophylline in the preterm infant (5). Moreover the renal effects of caffeine have not been extensively investigated in the neonatal period although some data suggest the absence of gross diuresis or electrolyte abnormalities $(1,6)$. Therefore we evaluated the acute renal effects of a single dose of theophylline ethylenediamine (aminophylline, $81 \%$ theophylline) or sodium benzoate caffeine in New Zealand White newborn rabbits whose renal maturation shows close similarities with that of premature infants (7). The methylxanthine doses were selected in the range of the usual therapeutic doses used in human neonates (1).

\section{MATERIALS AND METHODS}

Studies were performed in 59 newborn New Zealand rabbits aged 5 to 10 days. Animals were born by spontaneous vaginal delivery and afterward housed with the maternal rabbit and breast-fed. Newborn rabbits were initially anaesthetized with sodium pentobarbital, $25 \mathrm{mg} / \mathrm{kg}$ by intraperitoneal route. Small doses of $\mathrm{Na}$ pentobarbital were subsequently administered as necessary. A tracheal cannulation allowed mechanical ventilation with a mixture of air and oxygen (Rodent ventilator, model 683, Harvard, Millis, MA). A stretched PE 10 polyethylene tubing was inserted into the right femoral artery for arterial blood sampling and monitoring of systemic blood pressure.

A second catheter was similarly placed into the right femoral vein for solute infusion and drug administration. Surgical procedures and vascular cannulations were performed under stereoscopic magnifying glass (Zeiss, Oberkochen, Germany).

The bladder was catheterized for urine collection in preweighed microtest tubes. During the surgical procedure and subsequent experimental periods the body temperature of the newborn rabbits was kept at $38-38^{\circ} 5 \mathrm{C}$ using an infrared lamp and a warming operating table.

Throughout the experiment heart rate (Sanborn 780-3 videoscope, Hewlett Packard, 78332, Palo Alto, CA), blood pressure (Grass Polygraph, model 7B, Quincy, MA), and esophageal temperature (Digital thermometer, Poliak and Gramiger, EPFL, Lausanne, Switzerland) were continuously recorded. After completion of the surgical procedure priming doses of inulin (100 $\mathrm{mg} / \mathrm{kg})$ and PAH $(1.25 \mathrm{mg} / \mathrm{kg})$ were administered and a sustained infusion was given to maintain constant plasma inulin and PAH concentrations. The infusion rate was $1 \mathrm{ml} / 100 \mathrm{~g} / \mathrm{h}$ using a constant infusion pump (Perfusor EDL 2, Braun, Melsungen, Germany). The infusate contained per liter: $150 \mathrm{mmol}$ sodium, $5 \mathrm{mmol}$ potassium, $105 \mathrm{mmol}$ chloride, $50 \mathrm{mmol}$ bicarbonate, $50 \mathrm{~g}$ mannitol, $3 \mathrm{~g}$ inulin, and $150 \mathrm{mg}$ PAH. About $1 \mathrm{~h}$ was spent for animal preparation and $90 \mathrm{~min}$ for subsequent equilibration. Previously we demonstrated that blood pressure, heart rate, arterial $\mathrm{pH}, \mathrm{PO}_{2}, \mathrm{PCO}_{2}$, and renal functions remain stable for up to $3 \mathrm{~h}$ in this animal preparation $(7,8)$. 
The experimental protocol successively included a 1-h control period (I), the intravenous methylxanthine administration and two 1 -h study periods (II and III). Blood samples $(0.4 \mathrm{ml})$ were withdrawn at the midpoint of each urine collection period. Blood gas analysis, hematocrit and protein concentration measurements were conducted immediately. The red blood cells were reconstituted in human albumin and immediately returned to the animal. Plasma and urine samples were kept at $4^{\circ} \mathrm{C}$ for subsequent analysis.

A single dose of aminophylline or caffeine diluted in a $100 \mu \mathrm{l}$ saline vehicle was slowly $(5 \mathrm{~min})$ infused at the end of period $\mathrm{I}$. Aminophylline (Euphyllin R, BYK Gulden, Konstanz, Germany; $1 \mathrm{mg}$ of aminophylline ethylinediamine contains $0.81 \mathrm{mg}$ of theophylline) was administered as follows: $3 \mathrm{mg} / \mathrm{kg}$ (group $\mathrm{A} 1 ; n=8$ ) and $6 \mathrm{mg} / \mathrm{kg}$ (group A2; $n=9$ ). Caffeine prepared with sodium benzoate was administered as follows: $5 \mathrm{mg} / \mathrm{kg}$ (group $\mathrm{C} 1 ; n=8$ ) and $10 \mathrm{mg} / \mathrm{kg}$ (group C2; $n=10$ ).

Additional experiments were carried out to assess the renal PAH extraction ratio in 15 untreated newborn rabbits, five aminophylline $(6 \mathrm{mg} / \mathrm{kg})$ and four caffeine $(10 \mathrm{mg} / \mathrm{kg})$ treated rabbits ( $1 \mathrm{~h}$ after methylxanthines administration). Following a small laparotomy a fine needle was inserted into the left renal vein and venous blood was slowly extracted (approximately 0.04 $\mathrm{ml} / \mathrm{min}$ ) by a constant extraction pump (Perfusor EDL 2, Braun, Melsungen, Germany). At the end of the experiments the rabbits were killed with a lethal dose of pentobarbital.

The standard clearances $(\mathrm{C})$ of inulin and $\mathrm{PAH}$ were calculated from the formula:

$$
\mathrm{C}(\mathrm{ml} / \mathrm{min})=\mathrm{U} \times \mathrm{V} / \mathrm{P}
$$

where $U=$ urine concentration, $\mathrm{P}=$ plasma concentration, $\mathrm{V}=$ urine flow rate in $\mathrm{ml}$ per min per $\mathrm{kg}$. GFR, RBF, RVR, FF, and FENa were calculated from the following equations:

$$
\begin{gathered}
\text { GFR }(\mathrm{ml} / \mathrm{kg} / \mathrm{min})=\mathrm{C} \text { inulin } \\
\mathrm{RBF}(\mathrm{ml} / \mathrm{kg} / \mathrm{min})=\mathrm{C} \mathrm{PAH} /[\mathrm{E} \mathrm{PAH} \times(1-\mathrm{Hct})] \\
\mathrm{RVR}(\mathrm{mm} \mathrm{Hg} / \mathrm{ml} / \mathrm{kg} / \mathrm{min})=\text { blood } \mathrm{pressure} / \mathrm{RBF} \\
\mathrm{FF}(\%)=(\mathrm{C} \text { inulin } / \mathrm{C} \mathrm{PAH}) \times \mathrm{E} \mathrm{PAH} \times 100 \\
\mathrm{FENa}=(\mathrm{C} \mathrm{Na} / \mathrm{C} \text { inulin }) \times 100 .
\end{gathered}
$$

Analytical methods. The urine volume was calculated from the change in weight of preweighed tubes without correction for specific gravity (Analytical balance, Mettler, Greifensel, Zurich, Switzerland). Arterial blood for $\mathrm{pH}, \mathrm{PCO}_{2}, \mathrm{PO}_{2}$, and hematocrit determinations was collected anaerobically in heparinized capillary tubes. Blood gas determinations were performed using a $\mathrm{pH} /$ blood gas analyzer (Gas analyzer 168, Corning, Halsted, Essex, England). The automatic anthrone (9) and the Bratton and Marshall (10) methods were used for the determination of inulin and PAH concentrations, respectively (Autoanalyzer II, Technicon Instrument Corporation, Tarrygtown, NY). Sodium concentrations were determined by flame photometry (Flamephotometer 543, Instrument Laboratory, Lexington, MA). Plasma protein concentration was estimated from the plasma index of refraction, using a temperature compensated refractometer (AOTS meter, American Optical, Buffalo, NY). Statistical analysis (11) was performed by a one-way analysis of variance for age, weight, and E PAH comparisons. Time/treatment effect was tested using the two-way analysis of variance for repeated measures. When a significant $(p<0.05)$ effect was found, differences within each pair of means was tested by the Student's method using the residual variance given by the analysis. All computations were done using the Triomphe software which has been developed at the Department of Medical Information in Dijon Hospital, Dijon, Cedex, France. All values are expressed as means \pm SEM.

\section{RESULTS}

Mean ages and weights were similar in the four groups (A1: $7.8 \pm 0.5$ days; $127 \pm 5$ g. A2: $6.6 \pm 0.5$ days; $110 \pm 5$ g. C1: 6.7 \pm 0.6 days; $117 \pm 7$ g. C2: $6.4 \pm 0.3$ days; $108 \pm 5 \mathrm{~g})$. The mean PAH extraction ratio was similar in untreated $(55 \pm 4 \%)$, theophylline $(46 \pm 7 \%)$, and caffeine $(48 \pm 13 \%)$ treated rabbits. Thus RBF, RVR and FF were subsequently calculated assuming the same E PAH value (55\%) for treated and untreated animals.

Arterial $\mathrm{PO}_{2}$ was purposely maintained above $100 \mathrm{~mm} \mathrm{Hg}$ in order to avoid any hypoxemia-induced change in renal hemodynamics (12). No physiological parameters varied significantly in groups A1 and A2 (Table 1). As a consequence of repeated blood sampling Hct decreased from period I to period II in group $\mathrm{C} 2$ and from period I to period III in groups C1 and C2 (Table 2). Mean blood pressure, $\mathrm{PaCO}_{2}$, arterial $\mathrm{pH}$, and protein levels remained stable throughout the experiments in the caffeinetreated animals.

The changes in absolute V, GFR, RBF, RVR, FF, FENa, and $U / P$ inulin ratio values are given in Tables 3 and 4 . The following significant percent changes are noteworthy. Group A1: a decrease in GFR $(-45 \pm 9 \%)$ and RBF $(-46 \pm 8 \%)$ associated with an increase in RVR $(+123 \pm 45 \%)$ in period III. Group A2: an increase in GFR $(+31 \pm 6 \%)$ in period II; a decrease in RBF $(-37 \pm 8 \%)$ and an increase in RVR $(+57 \pm 18 \%)$ in period III. Group C2: an increase in GFR $(+29 \pm 11 \%)$ in period II; an increase in RVR $(+36 \pm 15 \%)$ in period III.

\section{DISCUSSION}

Systemic administration of MX to newborn rabbits induced changes in GFR and renal hemodynamics in a manner related to the kind and dose of MX and to the time elapsed after MX administration. GFR and renal hemodynamics did not change in the low-dose caffeine group $(5 \mathrm{mg} / \mathrm{kg})$. An early increase of GFR was observed after high-dose aminophylline or caffeine and a delayed decrease after low-dose aminophylline. RVR remained unchanged in rabbits infused with $5 \mathrm{mg} / \mathrm{kg}$ caffeine but experienced a delayed increase with the higher caffeine regimen (10 $\mathrm{mg} / \mathrm{kg}$ ). No significant change in RBF or FF was observed at either dose of caffeine. The systemic infusion of 2.5 and $5 \mathrm{mg} /$ $\mathrm{kg}$ theophylline (i.e. 3 and $6 \mathrm{mg} / \mathrm{kg}$ aminophylline) was associated with an increase in total RVR concomitant with a delayed but marked fall in RBF.

These renal hemodynamic changes after systemic administration of theophylline appear different from those observed after intrarenal infusion of theophylline, a condition inducing either a rise in GFR and RBF with an associated decline in RVR (13, 14) or no change in RBF, FF, or GFR, when low doses of theophylline were administered to mature animals $(15,16)$. The discrepancies between MX systemic and intrarenal administration could be related to differences in experimental conditions, namely, a) the duration of renal follow-up after theophylline administration, b) the specific characteristics of the renal response of the immature kidney to theophylline, and c) additive systemic extrarenal effects of the MX. The small but insignificant increase in blood pressure observed in groups A2 $(6 \mathrm{mg} / \mathrm{kg}$ aminophylline) and $\mathrm{C} 2(10 \mathrm{mg} / \mathrm{kg}$ caffeine) suggests a possible inotropic cardiovascular effect mediated by an increase in sympathetic neuronal tone and/or in adrenomedullary catecholamine release (17-19).

In newborn rabbits administered theophylline in a slow 5-min injection, plasma theophylline concentrations decline by $24 \pm$ $4 \%$ within $2 \mathrm{~h}$ (Gouyon J-B, Guignard J-P, unpublished data). Theophylline levels determined at the end of the experiments in groups A1 and A2 were $2.29 \pm 0.04 \mu \mathrm{g} / \mathrm{ml}(n=3)$ and $4.74 \pm$ $0.4 \mu \mathrm{g} / \mathrm{ml}(n=5)$, respectively. The renal hemodynamic effects of theophylline were observed at low doses and low plasma concentrations that cannot inhibit renal rabbit phosphodiesterase (20) but effectively antagonize renal adenosine receptors (21). Recent experimental data strongly suggest that renal adenosine could directly or indirectly induce a preglomerular vasoconstriction and an efferent arteriolar vasodilatation through stimulation of $\mathrm{A} 1$ and $\mathrm{A} 2$ adenosine receptors $(16,22-29)$. Thus, the significant increase in FF associated with $6 \mathrm{mg} / \mathrm{kg}$ aminophylline 
Table 1. Physiological data before (period I) and after (periods II and III) acute administration of aminophylline $3 \mathrm{mg} / \mathrm{kg}$ (group A1) or $6 \mathrm{mg} / \mathrm{kg}$ (group A2) in neonatal rabbits

\begin{tabular}{|c|c|c|c|c|c|c|}
\hline \multirow[b]{2}{*}{ Periods } & \multicolumn{3}{|c|}{ Group Al $(n=8)$} & \multicolumn{3}{|c|}{ Group A2 $(n=9)$} \\
\hline & I & II & III & I & II & III \\
\hline $\mathrm{PaO}_{2}(\mathrm{~mm} \mathrm{Hg})$ & $143 \pm 23$ & $172 \pm 14$ & $177 \pm 21$ & $169 \pm 13$ & $155 \pm 15$ & $164 \pm 19$ \\
\hline $\mathrm{PaCO}_{2}(\mathrm{~mm} \mathrm{Hg})$ & $41.0 \pm 3.3$ & $40.1 \pm 2.6$ & $38.5 \pm 2.3$ & $37.6 \pm 0.7$ & $38.5 \pm 1.3$ & $36.3 \pm 1.4$ \\
\hline $\mathrm{pH}$ & $7.46 \pm 0.02$ & $7.46 \pm 0.01$ & $7.47 \pm 0.02$ & $7.50 \pm 0.01$ & $7.48 \pm 0.01$ & $7.49 \pm 0.01$ \\
\hline Hct $(\%)$ & $31.4 \pm 1.3$ & $29.4 \pm 1.5$ & $29.4 \pm 0.8$ & $30.6 \pm 1.9$ & $29.5 \pm 2.0$ & $29.9 \pm 1.7$ \\
\hline Protein level ( $\mathrm{g} /$ liter) & $35.3 \pm 1.2$ & $34.1 \pm 1.4$ & $33.9 \pm 1.2$ & $31.3 \pm 1.7$ & $31.6 \pm 1.9$ & $32.0 \pm 1.9$ \\
\hline $\mathrm{MBP}(\mathrm{mm} \mathrm{Hg})$ & $32.0 \pm 1.5$ & $31.9 \pm 1.4$ & $31.2 \pm 2.3$ & $32.3 \pm 1.7$ & $35.7 \pm 1.8$ & $36.2 \pm 2.2$ \\
\hline
\end{tabular}

Table 2. Physiological data before (period I) and after (periods II and III) acute administration of caffeine $5 \mathrm{mg} / \mathrm{kg}$ (group Cl) or $10 \mathrm{mg} / \mathrm{kg}$ (group C2) in neonatal rabbits

\begin{tabular}{|c|c|c|c|c|c|c|}
\hline \multirow[b]{2}{*}{ Periods } & \multicolumn{3}{|c|}{ Group C1 $(n=8)$} & \multicolumn{3}{|c|}{ Group C2 $(n=10)$} \\
\hline & I & II & III & $\mathrm{I}$ & II & III \\
\hline $\mathrm{PaO}_{2}(\mathrm{~mm} \mathrm{Hg})$ & $102 \pm 7$ & $129 \pm 8^{*}$ & $131 \pm 11^{*}$ & $165 \pm 18$ & $170 \pm 21$ & $166 \pm 14$ \\
\hline $\mathrm{PaCO}_{2}(\mathrm{~mm} \mathrm{Hg})$ & $40.2 \pm 1.4$ & $41.6 \pm 1.8$ & $41.8 \pm 2.1$ & $36.5 \pm 2.4$ & $41.2 \pm 2.9$ & $38.4 \pm 2.6$ \\
\hline $\mathrm{pH}$ & $7.44 \pm 0.01$ & $7.43 \pm 0.01$ & $7.43 \pm 0.01$ & $7.48 \pm 0.03$ & $7.45 \pm 0.03$ & $7.46 \pm 0.03$ \\
\hline Hct $(\%)$ & $32.3 \pm 1.3$ & $31.4 \pm 1.4$ & $30.8 \pm 1.6^{*}$ & $30.7 \pm 1.2$ & $29 \pm 1.3^{*}$ & $28 \pm 1.6 \dagger$ \\
\hline Protein level (g/liter) & $37.8 \pm 2.4$ & $35.6 \pm 1.5$ & $34.4 \pm 2.3$ & $31.9 \pm 2.0$ & $30.3 \pm 1.2$ & $31.0 \pm 1.9$ \\
\hline $\mathrm{MBP}(\mathrm{mm} \mathrm{Hg})$ & $27.8 \pm 1.8$ & $28.0 \pm 1.9$ & $28.3 \pm 2.0$ & $28.4 \pm 1.6$ & $30.4 \pm 1.6$ & $29.6 \pm 2.0$ \\
\hline
\end{tabular}

Significant variations when comparing values of periods II and III to period I: ${ }^{*} p<0.025 ; \dagger p<0.01$.

Table 3. Kidney function parameters before (period I) and after (periods II and III) acute administration of aminophylline 3 mg/kg (group Al) or $6 \mathrm{mg} / \mathrm{kg}$ (group A2) in neonatal rabbits

\begin{tabular}{|c|c|c|c|c|c|c|}
\hline \multirow[b]{2}{*}{ Periods } & \multicolumn{3}{|c|}{ Group A1 $(n=8)$} & \multicolumn{3}{|c|}{ Group A2 $(n=9)$} \\
\hline & I & II & III & I & II & III \\
\hline $\mathrm{V}(\mathrm{ml} / \mathrm{kg} / \mathrm{min})$ & $0.05 \pm 0.003$ & $0.06 \pm 0.004^{*}$ & $0.04 \pm 0.007$ & $0.064 \pm 0.003$ & $0.107 \pm 0.007 \dagger$ & $0.084 \pm 0.012$ \\
\hline $\mathrm{GFR}(\mathrm{ml} / \mathrm{kg} / \mathrm{min})$ & $1.6 \pm 0.19$ & $1.61 \pm 0.23$ & $0.87 \pm 0.16 \dagger$ & $1.84 \pm 0.17$ & $2.43 \pm 0.26 \dagger$ & $1.75 \pm 0.26$ \\
\hline $\mathrm{RBF}(\mathrm{ml} / \mathrm{kg} / \mathrm{min})$ & $16.7 \pm 1.3$ & $16.6 \pm 1.4$ & $9.2 \pm 1.8 \dagger$ & $19.9 \pm 2.4$ & $19.8 \pm 2.6$ & $14.0 \pm 2.6 \dagger$ \\
\hline $\mathrm{RVR}(\mathrm{mm} \mathrm{Hg} / \mathrm{ml} / \mathrm{kg} / \mathrm{min})$ & $2.0 \pm 0.18$ & $1.98 \pm 0.13$ & $4.24 \pm 0.66 \dagger$ & $1.82 \pm 0.23$ & $2.13 \pm 0.45$ & $4.04 \pm 1.13^{*}$ \\
\hline $\mathrm{FF}(\%)$ & $14.4 \pm 1.8$ & $14.1 \pm 2.0$ & $14.1 \pm 1.5$ & $14.6 \pm 1.4$ & $19.2 \pm 1.5 \dagger$ & $20.6 \pm 1.5 \dagger$ \\
\hline FENa (\%) & $0.36 \pm 0.11$ & $0.69 \pm 0.25$ & $0.63 \pm 0.26$ & $0.75 \pm 0.24$ & $1.43 \pm 0.28$ & $1.55 \pm 0.43$ \\
\hline $\mathrm{U} / \mathrm{P}$ inulin & $31.6 \pm 2.7$ & $25.4 \pm 3.3 \dagger$ & $20.2 \pm 2.0 \dagger$ & $29.0 \pm 2.1$ & $22.5 \pm 1.4 \dagger$ & $20.8 \pm 1.6 \dagger$ \\
\hline
\end{tabular}

Significant variations when comparing values of periods II and III to period I: ${ }^{*} p<0.05 ; \uparrow p<0.01$.

Table 4. Kidney function parameters before (period I) and after (periods II and III) acute administration of caffeine $5 \mathrm{mg} / \mathrm{kg}$ (group C1) or $10 \mathrm{mg} / \mathrm{kg}$ (group C2) in neonatal rabbits

\begin{tabular}{|c|c|c|c|c|c|c|}
\hline \multirow[b]{2}{*}{ Periods } & \multicolumn{3}{|c|}{ Group Cl $(n=8)$} & \multicolumn{3}{|c|}{ Group C2 $(n=10)$} \\
\hline & I & II & III & I & II & III \\
\hline $\mathrm{V}(\mathrm{ml} / \mathrm{kg} / \mathrm{min})$ & $0.065 \pm 0.006$ & $0.088 \pm 0.016$ & $0.085 \pm 0.018$ & $0.056 \pm 0.005$ & $0.097 \pm 0.001^{*}$ & $0.096 \pm 0.011^{*}$ \\
\hline $\mathrm{GFR}(\mathrm{ml} / \mathrm{kg} / \mathrm{min})$ & $1.54 \pm 0.26$ & $2.16 \pm 0.41$ & $2.00 \pm 0.45$ & $1.49 \pm 0.17$ & $1.83 \pm 0.19 \dagger$ & $1.52 \pm 0.19$ \\
\hline $\mathrm{RBF}(\mathrm{ml} / \mathrm{kg} / \mathrm{min})$ & $16.1 \pm 2.9$ & $17.8 \pm 2.9$ & $18.1 \pm 3.4$ & $16.4 \pm 3.7$ & $17.1 \pm 3.3$ & $12.5 \pm 2.8$ \\
\hline $\operatorname{RVR}(\mathrm{mm} \mathrm{Hg} / \mathrm{ml} / \mathrm{kg} / \mathrm{min})$ & $2.11 \pm 0.33$ & $1.96 \pm 0.35$ & $2.04 \pm 0.40$ & $2.09 \pm 0.34$ & $1.97 \pm 0.29$ & $2.87 \pm 0.56 \dagger$ \\
\hline $\mathrm{FF}(\%)$ & $15.1 \pm 1.2$ & $17.7 \pm 1.5$ & $19.8 \pm 2.2$ & $13.5 \pm 2.6$ & $14.3 \pm 1.7$ & $16.9 \pm 1.8$ \\
\hline FENa (\%) & $0.86 \pm 0.31$ & $0.59 \pm 0.17$ & $0.57 \pm 0.12$ & $0.76 \pm 0.14$ & $1.23 \pm 0.17 \dagger$ & $1.39 \pm 0.21 \dagger$ \\
\hline $\mathrm{U} / \mathrm{P}$ inulin & $24.1 \pm 3.6$ & $24.5 \pm 3.2$ & $22.5 \pm 3.3$ & $27.1 \pm 2.7$ & $20.1 \pm 1.3^{*}$ & $16.6 \pm 0.9^{*}$ \\
\hline
\end{tabular}

Significant variations when comparing values of periods II and III to period I: ${ }^{*} p<0.01 ; \dagger p<0.025$.

administration in newborn rabbits could reflect changes in the ratio of arteriolar afferent to efferent tone rather than a decrease in the ultrafiltration coefficient $\mathrm{K}_{\mathrm{f}}$ [adenosine, the target of theophylline, does not alter glomerular capillary hydraulic conductivity (30)] or changes in oncotic pressure in the glomerular capillaries (seric protein levels remained stable throughout the experiments). Noteworthy is the fact that the changes in FF were only significant in the rabbits receiving theophylline, a more potent adenosine antagonist than caffeine (31), and that theophylline induced FF changes in a dose-related manner.

Acute theophylline and caffeine administration increases diuresis and natriuresis in rats (32), dogs (13), man (4), and possibly in human neonates (33). In newborn rabbits changes in diuresis were also present and can be related both to an increase in GFR and a decline in tubular water reabsorption, as suggested by the decrease in U/P inulin ratio. The natriuretic effect was only significant in animals administered $10 \mathrm{mg} / \mathrm{kg}$ caffeine.

As recently reported by Baer et al. (32) and Takeuchi et al. (34) theophylline causes simultaneous increases in urine flow rate and sodium and urinary PGE2 excretion. However, enprofylline (3-propylxanthine), a xanthine derivative with low adenosine antagonistic properties, also increases urinary PGE2 excretion (32) but does not elicit a natriuretic or a diuretic effect (32, 35 ). Thus the diuretic and natriuretic effects of theophylline 
cannot be ascribed simply to an increase in renal PGs. Furthermore, Woodcock et al. $(36,37)$ recently described A2 (RA) adenosine receptors in rats and human renal papillae, probably located in the collecting tubule. These authors hypothesized that stimulation of adenylate cyclase-coupled adenosine receptors in the renal papilla could produce an increase in hydraulic conductivity of the collecting tubule $(36,37)$ while inhibition of these receptors by theophylline and caffeine could reduce water tubule reabsorption at this tubular site.

The present data demonstrate that the renal effects of methylxanthines are dose- and time-related and suggest that acute low-dose caffeine $(5 \mathrm{mg} / \mathrm{kg})$ could prove safer than theophylline to control apn a, especially in very low birth weight infants who present with pnysiological low GFR and RBF (38) that can be furither depressed by various perinatal stresses (39).

Acknowledgments. The authors thank Ms. M. Thonney, Mr. P. d'Athis, Dr. F. Zihlmann, and Dr. M. Arnaud for valuable assistance.

\section{REFERENCES}

1. Brouard C, Moriette G, Murat I, Flouvat B, Pajot N, Walti H, De Gamarra E, Relier JP 1985 Comparative efficacy of theophylline and caffeine in the treatment of idiopathic apnea in premature infants. Am J Dis Child 139:698700

2. Murat I, Moriette G, Blin MC, Couchard M, Flouvat B, De Gamarra E, Relier JP, Dreyfus-Brisac C 1981 The efficacy of caffeine in the treatment of recurrent idiopathic apnea in premature infants. J Pediatr 99:984-989

3. Shannon DC, Gotay F, Stein IM, Rogers MC, Todres ID, Moylan FMB 1975 Prevention of apnea and bradycardia in low birth weight infants. Pediatrics 55:589-594

4. Rall TW 1985 Central nervous system stimulants: the methylxanthines. In: Goodman S, Gilman A (eds) The Pharmacologic Basis of Therapeutics, 7th ed. Macmillan, New York, pp 589-603

5. Howell J, Clozel M, Aranda JV 1981 Adverse effects of caffeine and theophylline in the newborn infant. Semin Perinatol 5:359-369

6. Rothberg AD, Marks KH, Ward RM 1981 The metabolic effects of caffeine in the newborn infant. Pediatr Pharmacol (New York) $1: 181-186$

7. Cotting J, Guignard JP 1982 Postnatal development of renal function in the newborn rabbit. Kidney Int 21:904-905

8. Heijden vd A, Guignard JP 1986 Effect of hypercapnic acidosis on renal function in the newborn rabbit. Pediatr Res 20:798-801

9. Wright HK, Gann DS 1966 An automatic anthrone method for the determination of inulin in plasma and urine. $\mathrm{J}$ Lab Clin Med 67:689-693

10. Bratton AC, Marshall EK Jr 1939 A new coupling component for sulfanilamide determination. J Biol Chem 128:537-550

11. Snedecor GW, Cochran WG 1967 Statistical Methods, 6th ed. Iowa State University Press, Ames

12. Boda D, Belay M, Eck E, Csernay L 1971 Blood distribution of the organs examined by ${ }^{86} \mathrm{Rb}$ uptake under intrauterine conditions and in the newborn, in normal and hypoxic rabbits. Biol Neonate 18:71-77

13. Kover G, Tost H, Stimacz E 1972 Effect of cyclic $3^{\prime}-5^{\prime}$-adenosine monophosphate and theophylline on renal function. Acta Physiol Acad Sci Hung 42:111-117

14. Ludens JH, Willis LR, Williamson HE 1970 The effect of aminophylline on renal hemodynamics and sodium excretion. Arch Int Pharmacodyn $185: 274-286$
15. Premen AJ, Hall JE, Mizelle HL, Cornell JE 1985 Maintenance of renal autoregulation during infusion of aminophylline or adenosine. Am J Physiol 248:F366-373

16. Spielman WS 1984 Antagonistic effect of theophylline on the adenosineinduced decrease in renin release. Am J Physiol 247:F246-251

17. Higbee MD, Kumar M, Galant SP 1982 Stimulation of endogenous catecholamine release by theophylline: a proposed additional mechanism of action for theophylline effects. J Allergy Clin Immunol 70:377-382

18. Robertson D, Frolich JC, Carr RK, Watson JT, Hollifield JW, Shand DG, Oates JA 1978 Effects of caffeine on plasma renin activity, catecholamines and blood pressure. $\mathrm{N}$ Engl J Med 298:181-186

19. Vestal RE, Eiriksson CE, Musser B, Ozaki LK, Halter JB 1983 Effect of intravenous aminophylline on plasma levels of catecholamines and related cardiovascular and metabolic responses in man. Circulation 67:162-171

20. Hedqvist P, Fredholm BB, Ölundh S 1978 Antagonistic effects of theophylline and adenosine on adrenergic neuroeffector transmission in the rabbit kidney. Circ Res 43:592-598

21. Persson CGA, Andersson KE, Kjellin G 1986 Effects of enprofylline and theophylline may show the role of adenosine. Life Sci 38:1057-1072

22. Haas JA, Osswald H 1981 Adenosine induced fall in glomerular capillary pressure. Effect of ureteral obstruction and aortic constriction in the MunichWistar rat kidney. Naunyn Schmiedebergs Arch Pharmacol 317:86-89

23. Hall JE, Granger JP, Hester RL 1985 Interactions between adenosine and angiotensin II in controlling glomerular filtration. Am J Physiol 248:F340346

24. Hall JE, Granger GP 1986 Renal hemodynamics and arterial pressure during chronic intrarenal adenosine infusion in conscious dogs. Am J Physiol 250:F32-39

25. Murray RD, Churchill PC 1984 Effects of adenosine receptor agonists in the isolated, perfused rat kidney. Am J Physiol 247:H343-348

26. Osswald $\mathrm{H} 1975$ Renal effects of adenosine and their inhibition by theophylline in dogs. Naunyn Schmiedebergs Arch Pharmacol 288:79-86

27. Osswald H, Schmitz HJ, Kemper R 1978 Renal action of adenosine: effect on renin secretion in the rat. Naunyn Schmiedebergs Arch Pharmacol 303:9599

28. Spielman WS, Thompson CI 1982 A proposed role for adenosine in the regulation of renal hemodynamics and renin release. Am J Physiol 242:F423-435

29. Tagawa H, Vander AJ 1970 Effects of adenosine compounds on renal function and renin secretion in dogs. Circ Res 26:327-338

30. Osswald H, Spielman WS, Knox FG 1978 Mechanism of adenosine-mediated decreases in glomerular filtration rate in dogs. Circ Res 43:465-469

31. Fredholm BB 1982 Adenosine receptors. Med Biol 60:289-293

32. Baer PG, Armstrong EL, Cagen LM 1983 Dissociation of effects of xanthines analogs on renal prostaglandins and renal excretory function in the awake rat. J Pharmacol Exp Ther 227:600-604

33. Harkavy KL, Scanlon JW, Jose P 1979 The effects of theophylline on renal function in the premature newborn. Biol Neonate 35:126-130

34. Takeuchi K, Kogo H, Aizawa Y 1981 Effects of methylxanthines on urinary prostaglandin E excretion in rats. Jpn J Pharmacol 31:253-259

35. Andersson KE Johannesson N, Karlberg B, Persson CGA 1984 Increase in plasma free fatty acids and natriuresis by xanthines may reflect adenosine antagonism. Eur J Clin Pharmacol 26:33-38

36. Woodcock EA, Loxley R, Leung E, Johnston CI 1984 Demonstration of RAadenosine receptors in rat renal papillae. Biochem Biophys Res Commun $121: 434-440$

37. Woodcock EA, Leung E, Johnston CI 1986 Adenosine receptors in papilla of human kidneys. Clin Sci 70:353-357

38. Guignard JP, John EG 1986 Renal function in the tiny, premature infant. Clin Perinatol 13:377-401

39. Guignard JP 1982 Renal function in the newborn infant. Pediatr Clin North Am 29:777-790 